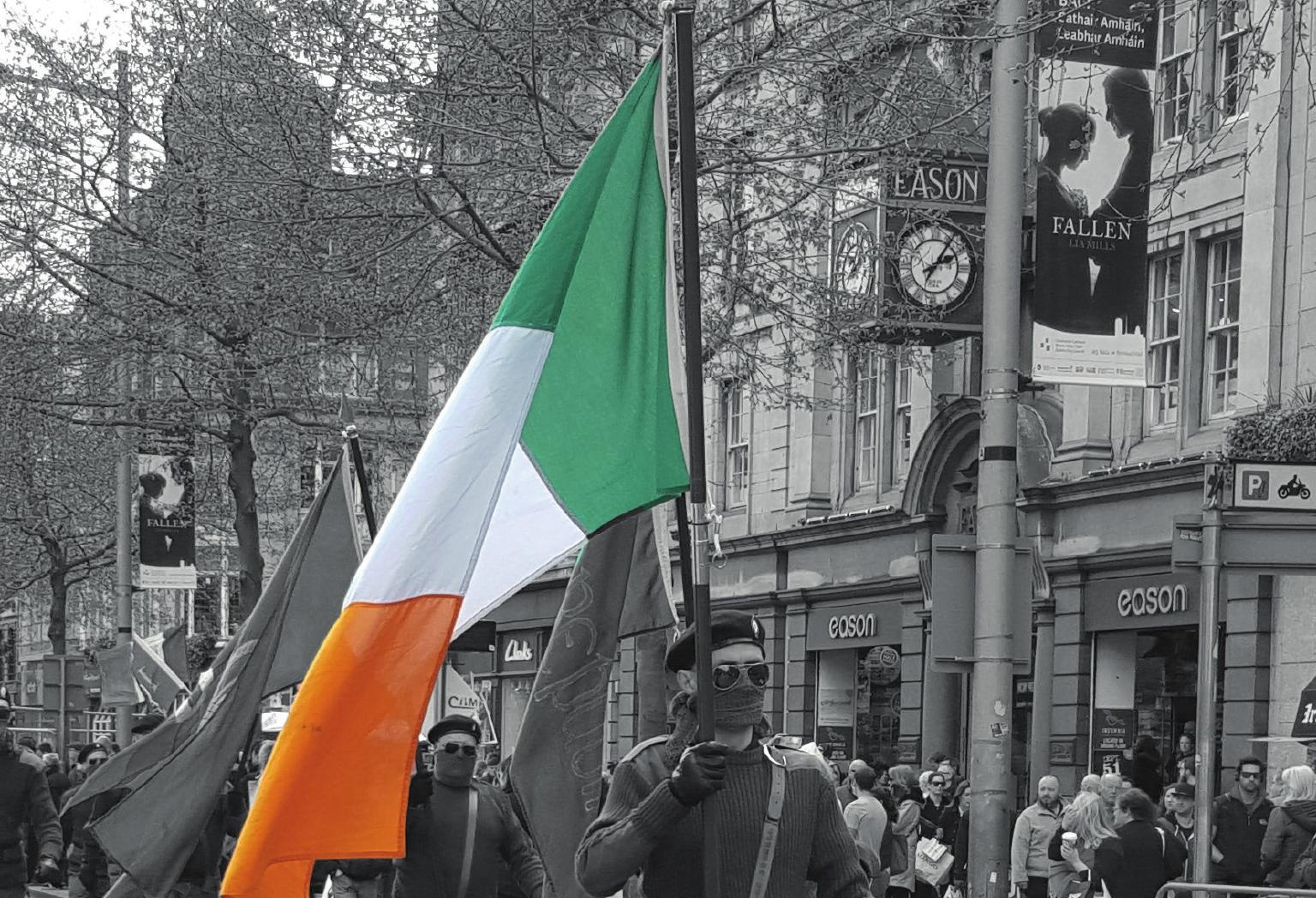

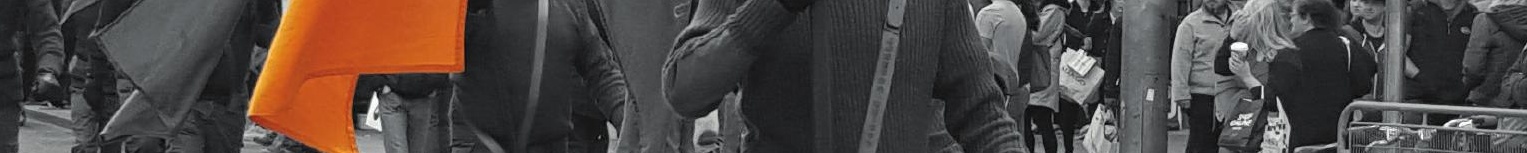
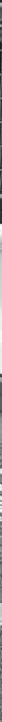

TIE PULIIIES OF 'DISSIDENT'
IRISI REPUBLICANISM

MARSA MGGLIGEE 


\section{Unfinished business}

\section{MANCHESTER 1824}

Manchester University Press 
Marisa McGlinchey - 9781526116215 Downloaded from manchesterhive.com at 04/26/2023 01:39:29PM via free access 


\section{Unfinished business}

The politics of 'dissident' Irish republicanism

MARISA McGLINCHEY

Manchester University Press 
Copyright (C) Marisa McGlinchey 2019

The right of Marisa McGlinchey to be identified as the author of this work has been asserted by her in accordance with the Copyright, Designs and Patents Act 1988.

Published by Manchester University Press

Altrincham Street, Manchester M1 7JA

www.manchesteruniversitypress.co.uk

British Library Cataloguing-in-Publication Data

A catalogue record for this book is available from the British Library

ISBN 9780719096976 hardback

ISBN 9780719096983 paperback

First published 2019

The publisher has no responsibility for the persistence or accuracy of URLs for any external or thirdparty internet websites referred to in this book, and does not guarantee that any content on such websites is, or will remain, accurate or appropriate.

Typeset in 10.5/12.5 Adobe Garamond by Servis Filmsetting Ltd, Stockport, Cheshire 